\title{
Side Light: What Is This All About? A Letter
}

Mirella Klomp, scholar of practical theology and ordained minister in the Protestant Church in the Netherlands, to Christian congregations and parishes in the Netherlands.

Brothers and sisters in Christ,

Greetings! After nine editions of The Passion in our country, and after nine years of research on the phenomenon, I am about to complete a monograph on how Christian religion has changed in the Netherlands. The book deals with new quests for God that may arise in the context of the decline of church membership and church attendance. As church people you may wonder: 'so, what is in it for us?' Having leaned against the energy and will-power of producers and broadcasters for seven chapters, I am now writing to you to share two things the research has brought me. You may find it beneficial.

\section{The Passion Shows That the Impossible Is Possible}

This is the shortest summary of what the research has taught me. To stage an event on the passion of Jesus for millions of people in a late-modern 'secularised' culture would seem impossible, yet it has occurred. I have seen mothers and grandmothers in distress following the cross on Twitter; entrepreneurs and churches objecting to the whole event, people drinking beer and enjoying their view of the square while sitting in window frames, actors of disrepute being allocated leading roles, firemen carrying the neon-lit cross through the rebuilt area of their city. In the seven chapters of my book, a variety of people pass us by - each with their own story and their own meaning-making around the ritual - and I have just mentioned a few; there are many more people, more stories, more processes of meaning-making. The impossible is possible.

The producers and broadcasters also managed to include in the passion the impossible-yet-most-essential-element of Christianity: after the death of Jesus, his resurrection was staged as the ultimate scene of the event. During the closing credits of the broadcast following the crucifixion, cameras zoomed in on the audience in the square, where people were visibly touched by the event, some of them even cried. This resurrection makes visible how people cross the boundary of what is possible. It makes The Passion more than just a cool show of sounds and lights. The event touches upon fundamental grief; 
upon a desire that the death of a child is not the end, or that God can indeed return to one's life; upon the unimaginable occurence that one would ever partake in an event centred on a Christian narrative, either as spectator or as actor. There is life after suffering from an event that confronts an entrepreneur with lost revenues and orthodox Christians with the pain of a sacrilege.

The most exciting thing I learned from the scene of the apparition of Jesus is this: that resurrection is a process that occurs in this reality. The Passion is not just an immense sound and light show staging the resurrected Jesus, it also calls attention to the fact that resurrection can become real when a narrative that exceeds the borders of what is impossible is staged. This process of resurrection occurs not only in The Passion, but also in The Passion. It raises a question for the church to circle around and consider. The church might want to ask whether she herself participates in this resurrection process.

\section{Being Turned into Guests}

Let us go back in time for a moment, to join the two men who are returning home after the resurrection of Jesus (Luke 24:13-35). They are on their way to Emmaus, leaving the impressive events of Jerusalem - the crucifixion of Jesus and the things that took place after his death - behind them, literally and figuratively. They are walking away from the big city, and they are walking forlorn. Whilst they are on the move, discussing all that they have heard and seen, all of a sudden Jesus (a rather public figure! but they do not recognise him) comes near, and asks what they are talking about: "What are you discussing with each other?"

His question can be read as an inquiry regarding the topic of their conversation ("what is keeping you busy?"). It can also (and particularly when read together with the second question: "what things?"), be understood as: "what is this all about?", "these things that you are talking about, what do they mean?" "what is that, then, 'resurrection'?" As Jesus accompanies them on their way, the men respond. They tell this stranger what is on their minds. And they are so occupied with their own experiences, so full of their confusion and sadness, that they do not even recognise Jesus; Luke suggests that they do not seem to be very interested in the stranger; they do not pose him any questions. Do they even care about him?

The Emmaus story raises all kinds of questions about their conversation. Who talks to whom? Who is listening? Who is paying attention to the conversation partner? Who takes whom further in the discussion? Who helps to get a foothold when it comes to making deeper insights, when it comes to recognis- 
ing what matters? These questions are also relevant in a quest for God. Those who undertake a quest for God want to move forward. As church people, we want to learn, grow in faith, come closer to God. We want the church to be meaningful to ourselves and others in our society. We want to get somewhere. The Emmaus story offers a crucial suggestion for this quest: that those who want to make progress would do better not only to focus on what keeps them busy, but also to pay attention to others. Of course, churches are worried about declining membership and church attendance, a shortage of volunteers to organise and support their activities, a lack of clergy ordained to the ministry. Of course, they can consider The Passion to be kitschy, they can get annoyed about the whole event, or consider it to be a banal and desacralised rendition of a gospel narrative that has so many more layers of meaning. But, meanwhile, the question is whether we are really attentive to the other who may be able to take us further.

When they arrive in the village of Emmaus, the men recognise Jesus in the breaking of the bread. He has created the place where they find themselves at home. They realise that they have turned into his guests. They are not hosting him; he is the host at the dinner table. My research on The Passion turned out to do exactly this. Listening to producers, broadcasters and their audience for seven long chapters, paying attention to their questions, their stories, their efforts, made the roles of guest and host gradually change places. Now, after seven chapters, and at the end of the project, I have become a guest of the producers and broadcasters.

What if we are not the ones to decide what happens? What if we let go of the idea that we are the hosts, that we are in the lead? What is the effect of being turned into a guest? The Emmaus story suggests that being a guest is beneficial. My research project has been beneficial to me. The producers and broadcasters hosted the publication of this book, so to speak. But the project has a yield even beyond this book: it has also changed me as a Christian theologian. It has nourished my life in this world and my service in the church with faith, with hesitations and with critical questions. The project itself has turned into a new quest for God, in which I discover myself as a guest, and discover that I was searching (quite publicly) without recognising my quest.

At the dinner table, the men recognise Jesus: their eyes are opened. And, when he has vanished from their sight, they return to Jerusalem (that is, they progress on their way to God) and the conversation continues, not just amongst themselves, but even more so among all the others.

In any quest for God, may an open mind be yours. 